\title{
Nutritional risk and associated factors in elderly patients with congestive heart failure in a Brazilian cardiology hospital
}

\section{Risco nutricional e fatores associados em idosos com insuficiência cardiaca crônica admitidos em hospital especializado em cardiologia no Brasil}

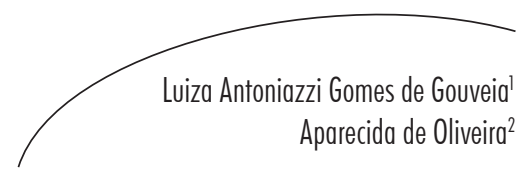

Abstract

Objective: To identify the nutritional risk and associated factors in elderly individuals with congestive heart failure admitted to a cardiology hospital. Methodology: A cross-sectional study collecting primary data was carried out in the Heart Institute of University of São Paulo. Nutritional risk was assessed using the Mini Nutritional Assessment (MNA). Data regarding sample (gender, age group, functional class of heart failure) was collected from medical records prior to application of the instrument. To test the association between nutritional status evaluated by MNA and independent variables, chi-square test and logistic regression were performed. Results: The study included 70 elderly individuals, 57\% males and 50\% between 60-69 years. Almost half of the group $(43 \%)$ was classified as "at risk of malnutrition." Among these, 60\% were 70 years or older ( $\mathrm{p}=0.005)$, categorized in functional classes III and IV $(48 \%, \mathrm{p}=0.025)$. Almost all of the "malnourished" or "at risk of malnutrition" elderly $(96 \%)$ reported at least $3 \mathrm{~kg}$ weight loss in the last 3 months ( $\mathrm{p}=0.003$ ), and $81 \%$ of the elderly who considered have health status worse than other elderly was malnourished $(p<0.001)$. Positive association was found between "risk of malnutrition" or be "malnourished" and functional class III and IV of the heart failure (OR 4.76; CI 1.46-15.51; $\mathrm{p}=0.010$ ), and at least $1 \mathrm{~kg}$ weight loss in the last 3 months (OR 6.17; CI 1.80-21.09; $\mathrm{p}=0.004$ ). Conclusion: Most of elderly were at malnourished or at risk of malnutrition. The factors associated with nutritional risk in elderly patients with congestive heart failure (age, functional class of heart failure, recent weight loss and self-assessment of health status) should be observed during routine clinical practice.

\footnotetext{
Departamento de Nutrição, Faculdade de Saúde Pública. Universidade de São Paulo. São Paulo, SP, Brasil.

2 Secretaria de Desenvolvimento Econômico, Ciência e Tecnologia, Centro Paula Souza. São Paulo, SP Brasil.
}

Key words: Nutritional Assessment. Elderly. Heart Failure. Malnutrition. 


\section{Resumo}

Objetivo: Identificar o risco nutricional e fatores associados em indivíduos idosos com insuficiência cardíaca crônica (ICC) admitidos em hospital cardiológico. Metodologia: Estudo transversal, com coleta de dados primários, realizado no Instituto do Coração (InCor) da Universidade de São Paulo. O risco nutricional foi avaliado pela Miniavaliação Nutricional (MAN). Os dados pessoais (sexo, grupo etário, classe funcional da ICC) foram coletados dos prontuários dos pacientes, antes da aplicação da MAN. Para testar a associação entre estado nutricional, avaliado pela MAN, e variáveis independentes, foram realizados o teste qui-quadrado e regressão logística. Resultados: Este estudo incluiu 70 idosos, 57\% homens e 50\% entre 60 e 69 anos de idade. Um pouco menos de metade dos idosos (43\%) foram classificados em "risco de subnutrição". Dentre estes, 60\% tinham 70 anos ou mais ( $\mathrm{p}=0,005)$, categorizados nas classes funcionais III e IV (48\%; $\mathrm{p}=0,025)$. Praticamente todos os idosos "subnutridos" e em "risco de subnutrição" (96\%) relataram perda de peso acima de 3 kg nos últimos três meses ( $\mathrm{p}=0,003)$, e $81 \%$ dos idosos que consideraram seu estado de saúde pior do que o de outros idosos eram "subnutridos" $(\mathrm{p}<0,01)$. Estar em "risco de subnutrição" ou "subnutridos" se associou positivamente com classe funcional III e IV da ICC (OR 4,76; IC 1,46-15,51; $\mathrm{p}=0,010)$, e perda de peso de pelo menos $1 \mathrm{~kg}$ nos últimos três meses (OR 6,17; IC 1,80-21,09; p=0,004). Conclusão: A maioria dos idosos estava subnutrida ou em risco de subnutrição. Os fatores associados com risco nutricional em idosos com insuficiência cardíaca crônica (idade, classe funcional da ICC, perda de peso recente e autoavaliação do estado de saúde) devem ser observados na prática clínica.
Palavras-chave: Avaliação Nutricional. Idoso. Insuficiência Cardíaca. Desnutrição.

\section{INTRODUCTION}

Advances in medicine along with fall in mortality rates have led to an increasing proportion of elderly worldwide., ${ }^{1,2}$ Biological aging is a phenomenon associated with changes in the activity of cells, tissues and organs, as well as reduced effectiveness of a number of physiological processes, rendering it hard to maintain good nutritional status. These changes can reduce quality of life and increase risk of both morbidity and mortality in this population group, predisposing the development of disease, notably cardiovascular pathologies. ${ }^{3-5}$

Congestive heart failure (CHF) is the most frequent cause of hospitalization for cardiovascular disease, accounting for $2.6 \%$ of hospitalizations and $6 \%$ of deaths recorded by The Brazilian National Health System (SUS) in 2007. Moreover, the rate of in-hospital mortality varies with age, being higher in elderly individuals. ${ }^{6}$
Among the elderly individuals, hospitalization represents a period of marked instability and compromised nutritional status which in turn can influence morbidity and mortality rates. ${ }^{7}$ The prevalence of malnutrition in hospitals ranges from 19 to $80 \%$ in medical and surgical patients, with higher rates seen among elderly individuals. ${ }^{8}$

Since the dawn of medicine, malnutrition has been recognized as a sign associated with cardiac insufficiency, particularly in its later stages. Varying degrees of protein-calorie depletion can be observed.' A Brazilian study in 53 patients hospitalized for CHF with a mean age of 57.7 years using Subjective Global Nutritional Assessment reported a prevalence of malnutrition of $60.4 \% .^{10}$

Cardiac patients with moderate or severe calorie malnutrition were found to have twice the mortality risk. Therefore, early identification of malnourished patients or those at risk of malnutrition is essential to enable the administration of nutritional 
therapy to correct nutritional changes and improve patient outcomes. ${ }^{10,11}$

The high prevalence of congestive heart failure in elderly individuals, who exhibit a tendency to reduce the body mass with the age increase, ${ }^{12}$ and the association between malnutrition and $\mathrm{CHF}$, create the need for studies aimed at early identification of nutritional risk in this population and investigation of its association with other variables, providing the rationale for the present study.

\section{METHODOLOGY}

A cross-sectional study entailing collection of primary data was carried out. All individuals aged 60 years or older participating in this study, were hospitalized in the Heart Institute of University of São Paulo, which treats patients with high complexity cardiovascular diseases between October and December 2009.

The data related to subject description (gender and age) were collected prior to application of the MNA from admission records. The diagnosis of congestive heart failure and the functional class classification was confirmed by medical notes from patient's medical records. Patients enrolled in the SUS, diagnosed with congestive heart failure on medical charts, and classified according to the proposal of The New York Heart Association (NYHA), ${ }^{13}$ without cognitive impairment and able to understand the questions and answer them verbally, were included.

NYHA classifies the severity of clinical disease and functional limitation, as described below:

- Class I: no limitation of physical activity. Ordinary physical activity does not cause undue fatigue, palpitation, or dyspnea.

- Class II: slight limitation of physical activity. Comfortable at rest, but ordinary physical activity results in fatigue, palpitations, or dyspnea.
- Class III: marked limitation of physical activity. Comfortable at rest, but less than ordinary activity causes fatigue, palpitation, or dyspnea, or marked limitation of physical activity. Comfortable at rest, but minimal exertion causes fatigue, palpitation, or dyspnea.

- Class IV: unable to carry on any physical activity without discomfort. Symptoms of cardiac insufficiency present at rest. If any physical activity is undertaken, discomfort is increased.

Patients receiving enteral feeding, exclusively or partially, were excluded from the study.

\section{Assessment of nutritional risk}

Weight (kilograms) and height (meters) measurements were obtained using an electronic scale $\left(\right.$ Filizola ${ }^{\circledR}$ ) coupled with a stadiometer, and performed with minimal clothing and footwear removed. For those patients whose weight and height measurements could not be taken by conventional methods, specific formulas recommended for these estimates were employed. ${ }^{14,15}$ In such cases, a clinical adipometer (Lange $^{\circledR}$, Cambridge Scientific Industries, USA) was used to measure the extent of subscapular skinfold (millimeters).

The Mini Nutritional Assessment (MNA), ${ }^{16}$ a screening instrument includes questions about decreased food intake, recent weight loss, conditions of mobility, psychological stress or acute disease, and neuropsychological problems as well as body mass index (BMI), was used to assess nutritional risk, with initial screening as per recommendations for the instrument. All data were collected by the same nutritionist.

After summing scores, respondents were screened for continuation with the evaluation or otherwise, where those scoring less than or equal to 11 points were classified as "possible 
malnutrition" cases and proceeded with the evaluation according to the methodology of the instrument. ${ }^{16}$

After the screening process, the overall assessment of the MNA was applied to collect data on patient abode (home or geriatric institution), drug use, skin lesions or pressure sores, and nutritional information. The information on nutrition included average number of meals per day, dietary sources of protein, fruits, vegetables, liquids and self-feeding ability. In addition, participants performed a self-assessment of nutritional status and health, representing general perception about health, according to several biopsychosocial dimensions.

All patients undergoing the comprehensive MNA evaluation were measured for brachial perimeter (BP) and perimeter of the leg (PL) using an inelastic tape measure $(\mathrm{cm})$, based on specific measurement techniques and suggested score for the instrument. ${ }^{16}$

The final nutritional status of patients was evaluated according to the suggested score for the MNA: patients scoring higher than 23.5 were classified as "no nutritional risk"; those with 17 to 23.5 points were "at risk of malnutrition; while those scoring less than 17 points were classified as "malnourished". 16

This study was approved by the Research Ethics Committee of the Heart Institute of University of Sao Paulo (protocol number 3309/09/060) and by the Ethics Committee for analysis of research projects of Clinical Hospital of University of Sao Paulo (protocol number
0892/09). Participants were informed about the purpose of the study, its risks and the procedures involved. Subsequently, the subjects were invited to participate in the study by signing an informed consent term.

\section{Statistical analysis}

The description of the population for the distribution of the elderly individuals was expressed in absolute and relative frequencies, according to the study variables (gender and, age). To facilitate data analysis, the population was categorized into only two age groups, namely 60 to 69 years and 70 years or older, due to the small number of individuals, and the functional class into class I and II; and class III and IV, in order to group elderly with similar limitations.

The comparison of proportions was performed using the chi-square test. To test the association between nutritional status evaluated by MNA and independent variables, multiple logistic regression was used. The significance level adopted for all tests was $5 \%$ and the magnitude was tested by the odds ratio (OR) values and the confidence interval of 95\% (CI 95\%). The software used for statistical analysis was Stata ${ }^{\circledR}$ version 10.0.

\section{RESULTS}

The study included 70 elderly individuals, predominantly male (57\%) and aged from 60 to 69 $(50 \%)$. This data and other results characterizing the sample are shown in table 1. 
Table 1. Distribution of study population by gender, age group, nutritional risk classification and functional class. São Paulo-SP, 2010.

$\mathrm{AF} \quad \mathrm{RF}$

Gender

Male

40

$57 \%$

Female

30

$43 \%$

Age group

60-69

35

$50 \%$

$\geq 70$

35

$50 \%$

Nutritional risk classification

No nutritional risk

Risk of malnutrition

30

$43 \%$

Malnourished

24

$34 \%$

Functional class

Class I

6

$8 \%$

Class II

18

$26 \%$

Class III

35

$50 \%$

Class IV
$16 \%$

$\mathrm{AF}=$ absolute frequency; $\mathrm{RF}=$ relative frequency.

Almost half of the group (43\%) was classified as "at risk of malnutrition", with $77 \%$ of the elderly individuals in the study group comprising "malnourished" (34\%) and "risk of malnutrition", as shown in table 1. A statistically significant difference was observed across age groups for nutritional risk, where $51 \%$ of subjects from the 60 to 69 year group were classified as "malnourished", while 60\% from the group 70 years or older was classified as "risk of malnutrition" ( $\mathrm{p}=0.005)$, as shown in table 2. 
Table 2. Distribution of study population by nutritional risk classification and gender, age group, functional class of heart failure, weight loss in the last three months, and self-assessment of nutritional and of health status. São Paulo-SP, 2010.

\begin{tabular}{|c|c|c|c|c|c|}
\hline & $\begin{array}{c}\text { No } \\
\text { nutritional } \\
\text { risk (n) }\end{array}$ & $\begin{array}{c}\text { Risk of } \\
\text { malnutrition } \\
\text { (n) }\end{array}$ & $\begin{array}{l}\text { Malnourished } \\
\text { (n) }\end{array}$ & $\begin{array}{l}\text { Total } \\
\text { (n) }\end{array}$ & $\mathrm{p}$ value \\
\hline \multicolumn{6}{|l|}{ Gender } \\
\hline Male & $30 \%(12)$ & $45 \%(18)$ & $25 \%(10)$ & $100 \%(40)$ & 0.104 \\
\hline Female & $13 \%(4)$ & $40 \%(12)$ & $47 \%(14)$ & $100 \%(30)$ & \\
\hline \multicolumn{6}{|l|}{ Age group } \\
\hline $60-69$ & $23 \%(8)$ & $26 \%(9)$ & $51 \%(18)$ & $100 \%(35)$ & $0.005^{*}$ \\
\hline$\geq 70$ & $23 \%(8)$ & $60 \%(21)$ & $17 \%(6)$ & $100 \%(35)$ & \\
\hline \multicolumn{6}{|l|}{ Functional class } \\
\hline Class I and II & $42 \%(10)$ & $33 \%(8)$ & $25 \%(6)$ & $100 \%(24)$ & $0.025^{*}$ \\
\hline Class III and IV & $13 \%(6)$ & $48 \%(22)$ & $39 \%(18)$ & $100 \%(46)$ & \\
\hline \multicolumn{6}{|l|}{ Weight loss in the } \\
\hline \multicolumn{6}{|l|}{ last three months } \\
\hline $0 \mathrm{~kg}$ & $50 \%(10)$ & $35 \%(7)$ & $15 \%(3)$ & $100 \%(20)$ & \\
\hline $1-3 \mathrm{~kg}$ & $36 \%(5)$ & $43 \%(6)$ & $21 \%(3)$ & $100 \%(14)$ & $0.003 *$ \\
\hline$>3 \mathrm{~kg}$ & $4 \%(1)$ & $48 \%(14)$ & $48 \%(14)$ & $100 \%(29)$ & \\
\hline Do not know & $0 \%(0)$ & $43 \%(3)$ & $57 \%(4)$ & $100 \%(7)$ & \\
\hline \multirow{2}{*}{\multicolumn{6}{|c|}{$\begin{array}{l}\text { Self-assessment of } \\
\text { nutritional status }\end{array}$}} \\
\hline & & & & & \\
\hline Malnourished & $0 \%(0)$ & $31 \%(5)$ & $69 \%(11)$ & $100 \%(16)$ & \\
\hline Do not know & $0 \%(0)$ & $71 \%(5)$ & $29 \%(2)$ & $100 \%(7)$ & 0.129 \\
\hline No nutritional risk & $6 \%(2)$ & $61 \%(20)$ & $33 \%(11)$ & $100 \%(33)$ & \\
\hline \multicolumn{6}{|l|}{ Self-assessment of } \\
\hline \multicolumn{6}{|l|}{ health status } \\
\hline Worst & $0 \%(0)$ & $19 \%(4)$ & $81 \%(17)$ & $100 \%(21)$ & \\
\hline Do not know & $0 \%(0)$ & $76 \%(13)$ & $24 \%(4)$ & $100 \%(17)$ & $<0.001 *$ \\
\hline Equal & $10 \%(1)$ & $60 \%(6)$ & $30 \%(3)$ & $100 \%(10)$ & \\
\hline Better & $13 \%(1)$ & $87 \%(7)$ & $0 \%(0)$ & $100 \%(8)$ & \\
\hline
\end{tabular}


There was positive association between nutritional risk and functional class, 87\% functional class III and IV patients, were malnourished or at risk of malnutrition ( $\mathrm{p}=0.025)$. On some questions referring to weight loss and self-assessment of health status and nutritional status, a significant association was found between nutritional risk and weight loss over the last three months $(\mathrm{p}=0.003)$ and patient opinion on own health $(\mathrm{p}<0.001)$. Of those elderly individuals who reported no weight loss over the past three months, 50\% were classified as "no nutritional risk," while $64 \%, 96 \%$ and $100 \%$ of patients that reported a loss of 1 to $3 \mathrm{~kg}$, more than $3 \mathrm{~kg}$ or not known, were classified as "at risk of malnutrition" or "malnourished", respectively (table 2).

Regarding self-assessment of health, $100 \%$ of subjects who considered their health worse than others of the same age were classified as "at risk of malnutrition" and "malnutrition", while 13\% of those who considered themselves in good health, were classified as "without nutritional risk." However, no association was found between selfassessed nutritional status and nutritional risk classification on the MNA, as shown in table 2.

The multiple logistic regression demonstrated that patients classified as functional class of CHF III and IV, reporting at least $1 \mathrm{~kg}$ weight loss and being female presented higher risk of be classified as "malnourished" or "risk of malnutrition" (OR 5.50, CI 1.49-20.34, $\mathrm{p}=0.011$; OR 4.30, CI 1.61-15.92, $\mathrm{p}=0.029$ and OR 4.35, CI $1.03-18.35, \mathrm{p}=0.045$, respectively). These associations remained independent of age group as demonstrated in multiple of logistic regression model $(\mathrm{p}=0.003)$ in table 3 .

Table 3. Association between malnourished/risk of malnutrition and independent variables. São PauloSP, 2010.

\begin{tabular}{|c|c|c|c|c|}
\hline Independent variables & OR & CI $(95 \%)$ & $\mathrm{p}$ value & $\mathrm{p}$ value of the model \\
\hline & & & & $0.003 *$ \\
\hline \multicolumn{5}{|l|}{ Functional class } \\
\hline Class I and II & 1 & & & \\
\hline Class III and IV & 5.50 & $1.49-20.34$ & $0.011 *$ & \\
\hline \multicolumn{5}{|l|}{ Weight loss in the } \\
\hline \multicolumn{5}{|l|}{ last three months } \\
\hline $0 \mathrm{~kg}$ & 1 & & & \\
\hline$\geq 1 \mathrm{~kg}$ & 4.30 & $1.61-15.92$ & $0.029 *$ & \\
\hline \multicolumn{5}{|l|}{ Gender } \\
\hline Male & 1 & & & \\
\hline Female & 4.35 & $1.03-18.35$ & $0.045^{*}$ & \\
\hline \multicolumn{5}{|l|}{ Age group } \\
\hline $60-69$ & 1 & & & \\
\hline$\geq 70$ & 0.75 & $0.21-2.75$ & 0.665 & \\
\hline
\end{tabular}




\section{DISCUSSION}

Several studies have evaluated the nutritional risk of elderly individuals, ${ }^{5,7,17-21}$ but only one study (using the MNA) assessed the risk of malnutrition in elderly patients with congestive heart failure. ${ }^{22}$ The study observed "risk of malnutrition" in $71 \%$ of men and $70 \%$ of women, while $5 \%$ of men and $15 \%$ of women were classified as "malnourished", showing higher prevalence of risk of malnutrition compared to the rate observed in the present study (45\% of men and $40 \%$ of women), and higher prevalence of "malnourished" compared to the rate observed in the present study (25\% of men and $47 \%$ of women). Similar data in the present study is that being female presented higher risk of be classified as "malnourished" or "risk of malnutrition". ${ }^{22}$

A number of studies have been carried out in elderly patients with congestive heart failure ${ }^{9,23-26}$ but with different objectives from those of the present study, difficulty comparisons with the findings of this research on associations between nutritional risk, weight loss and self-assessment of health status. Vedantam et al. ${ }^{27}$ applied the MNA in an elderly population in India, observing positive association between increasing age and risk of malnutrition. Another study involving a representative sample of 1.519 Brazilian elderly individuals showed that increasing age decreased the chance of obesity and overweight with an increased chance of low weight. ${ }^{28}$ In the present study, age was significantly associated with nutritional risk, with $87 \%$ of those aged 80 years and older classified as "risk of malnutrition" or "malnourished."

In a study carried out within a geriatric hospital in a sample of 83 patients, $69 \%$ of subjects were found to be at nutritional risk according to the MNA. ${ }^{29}$ Lower prevalence of malnutrition was observed in a population of hypertensive elderly $(12.8 \%)$, evaluated by the body mass index. ${ }^{30}$ High prevalence of nutritional risk was expected in our population, given the characteristics of congestive heart failure, favoring the appearance of various degrees of malnutrition.

Oliveira et al., ${ }^{31}$ in a study of a population of 240 elderly with a frequency of $37.1 \%$ of nutritional risk and $29.1 \%$ of malnutrition, found positive association between the worst MNA scores and weight loss in the last three months, as observed in this study.

In a study on the association between various factors and functional disability in elderly individuals revealing greater association with clinical conditions and increased risk of morbidity and subsequent mortality, a gradual worsening of self-assessment of health status was seen with increasing disability. ${ }^{32}$ In the present study, a significant association was observed between patient opinion on own health, functional class of $\mathrm{CHF}$ and MNA classification. Worsening of the limitations in CHF is usually accompanied by anorexia, fatigue and dyspnea, affecting the nutritional status. ${ }^{13}$

MNA is a practical tool that offers rapid implementation. However, the use of measures of arm circumference and perimeter of the leg, which may be altered due to edema common in this disease, represents a limitation in the application of the MNA in elderly patients with congestive heart failure, potentially underestimating nutritional risk.

The major limitations of this study was that the MNA was not applied early during the first two hours of hospitalization. Early application of the MNA in the first hours of hospitalization may facilitate recall by elderly individuals of their routine at home whereas a larger sample could also provide more meaningful results.

\section{CONCLUSIONS}

Most elderly individuals studied were at risk of malnutrition. Association was observed between malnourished or risk of malnutrition and age, gender, functional class of heart failure, body weight loss in the last three months, and self-assessment of health status. Age, gender, functional class, recent weight loss and selfassessment of health status should be observed during routine clinical practice, since these factors are associated with nutritional risk in elderly patients with congestive heart failure. 


\section{REFERENCES}

1. Instituto Brasileiro de Geografia e Estatística. Síntese dos Indicadores Sociais: uma análise das condições de vida da população brasileira 2008 [Internet]. Rio de Janeiro: IBGE; 2008 [acesso 17 mar 2009]. (Estudos \& Pesquisas, Informação Demográfica e Sócioeconômica; n. 23). Disponível em: http://www.ibge.gov.br/home/estatistica/ populacao/condicaodevida/indicadoresminimos/ sinteseindicsociais2008/indic_sociais2008.pdf

2. Bassler TC, Lei DLM. Diagnóstico e monitoramento da situação nutricional da população idosa em município da região metropolitana de Curitiba (PR). Rev Nutr 2008;21(3):311-21.

3. Sociedade Brasileira de Cardiologia. Diretrizes do Grupo de Estudos em cardiogeriatria da Sociedade Brasileira de Cardiologia. Arq Bras Cardiol 2002;79(suppl 1):1-46.

4. Paula HAA, Oliveira FCE, São José JFB, Gomide CI, Alfenas RCG. Avaliação do estado nutricional de pacientes geriátricos. Rev Bras Nutr Clin 2007;22(4):280-5.

5. Rebelatto JR, Jiménez R, Delgado MA, Muguerza B, Muñoz ME, Galan AI, et al. Antioxidantes, atividade física e estresse oxidativo em mulheres idosas. Rev Bras Med Esporte 2008;14(1):8-11.

6. Sociedade Brasileira de Cardiologia. III Diretriz Brasileira de insuficiência cardíaca crônica. Arq Bras Cardiol 2009;93(1 suppl 1):1-71.

7. Scattolin MAA, Avelar GN, Toledo JCF, Yamamoto FW, Alves ER, Dias Neto VS. Avaliação nutricional de idosos internados no CHS: perfil nutricional à internação e correlação com escala de depressão e mini-mental. Rev Fac Ciênc Méd Sorocaba 2005;7(1):11-4.

8. Maciel JRV, Oliveira CJR, Tada CMP. Associação entre risco de disfagia e risco nutricional em idosos internados em hospital universitário de Brasília. Rev Nutr 2008;21(4):411-21.

9. Veloso LG, Oliveira Júnior MT, Munhoz RT, Morgado PC, Ramires JAF, Barretto ACP. Repercussão nutricional na insuficiência cardíaca avançada e seu valor na avaliação prognóstica. Arq Bras Cardiol 2005;84(6):480-5.

10. Yamauti AK, Ochiai ME, Bifulco PS, Araújo MA, Alonso RR, Ribeiro RHC, et al . Avaliação nutricional subjetiva global em pacientes cardiopatas. Arq Bras Cardiol 2006;87(6):772-7.

11. Secher M, Soto ME, Villars H, Van Kan GA, Vellas B. The Mini Nutritional Assessment (MNA) after 20 years of research and clinical practice. Rev Clin Gerontol 2007;17(4):293-310.
12. Mastroeni MF, Mastroeni SSBS, Erzinger GS, Marucci MFN. Antropometria de idosos residentes no município de Joinville-SC, Brasil. Rev Bras Geriatr Gerontol 2010;13(1):29-40.

13. New York Heart Association, Criteria Committee. Nomenclature and criteria for diagnosis of diseases of the heart and great vessels. Dolgin M, editor. 9th ed. Boston: Little, Brown; 1994. 334 p.

14. Chumlea WC, Roche AF, Steinbaugh ML. Estimating stature from knee height for persons 60 to 90 years of age. J Am Diet Assoc 1985;33(2):116-20.

15. Chumlea WC, Guo SS, Roche AF, Steinbaugh ML. Prediction of body weight for the nonambulatory elderly from anthropometry. J Am Diet Assoc 1988;88(5):564-8.

16. Guigoz Y, Vellas B, Garry PJ. Mini Nutritional Assessment: a practical assessment tool for grading the nutritional state of elderly patients. Facts Res Gerontol 1994;4:15-59.

17. Arellano M, Garcia-Caselles MP, Pi-Figueras M, Miralles R, Torres RM, Aguilera A, et al. Clinical impact of different scores of the mini nutritional assessment (MNA) in the diagnosis of malnutrition in patients with cognitive impairment. Arch Gerontol Geriatr 2004;38 Suppl 9:27-31.

18. Bauer JM, Vogl T, Wicklein S, Trögner J. Mühlberg W. Sieber CC. Comparison of the mini nutritional assessment, subjective global assessment, and nutritional risk screening (NRS 2002) for nutritional screening and assessment in geriatric hospital patients. Z Gerontol Geriat 2005;38(5):322-7.

19. Cereda E, Valzolgher L, Pedrolli C. Mini nutritional assessment is a good predictor of functional status in institutionalised elderly at risk of malnutrition. Clin Nutr 2008;27(5):700-5.

20. Tsai AC, Ku PY, Tsai JD. Population-specific anthropometric cutoff standards improve the functionality of the mini nutritional assessment without BMI in institutionalized elderly in Taiwan. J Nutrition Health Aging 2008;12(10):696-700.

21. Cuervo M, Ansorena D, Martínez-González MA, García A, Astiasarán I, Martínez JA . Impact of global and subjective mini nutritional assessment (MNA) questions on the evaluation of the nutritional status: the role of gender and age. Arch Gerontol Geriatr 2009;49(1):69-73.

22. Oliveira A, Cardoso E, Isosaki M. Avaliação do risco de desnutrição de idosos com insuficiência cardíaca internados em hospital especializado em cardiologia. Rev Bras Nutr Clin 2003; 18(1):21-5. 
23. Barretto ACP, Del Carlo CH, Cardoso JN, Morgado PC, Munhoz RT, Eid MO, et al. Re-hospitalizações e mortes por insuficiência cardíaca: índices ainda alarmantes. Arq Bras Cardiol 2008;91(5):335-41.

24. Vasconcelos LABA, Almeida EA, Bachur LF. Avaliação Clínica e Laboratorial Hepática em Indivíduos com Insuficiência Cardíaca Congestiva. Arq Bras Cardiol 2007;88(5):590-5.

25. Veloso LG, Pereira-Barretto MC, Oliveira Júnior MT, Munhoz RT, Morgado PC, Ramires JAF. Escore para avaliação do estado nutricional: seu valor na estratificação prognóstica de portadores de cardiomiopatia dilatada e insuficiência cardíaca avançada. Arq Bras Cardiol 2006;87(2):178-84.

26. Parada ED, García FMS, Climent JCM, Garía AM, Gaona VL, Vara SG, et al. Variables asociadas a deterioro funcional al alta y a los 3 meses en ancianos hospitalizados por insuficiencia cardíaca. Rev Esp Geriatr Gerontol 2009;44(2):66-72.

27. Vedantam A, Subramanian V, Rao NV, John RK. Malnutrition in free-living elderly in rural south India: prevalence and risk factors. Public Health Nutr 2009;7:1-5.
28. Campos MAG, Pedroso ERP, Lamounier JA, Colosimo EA, Abrantes MM. Estado nutricional e fatores associados em idosos. Rev Assoc Med Bras 2006;52(4):214-21.

29. Persson MD, Brismar K, Katzarski KS, Nordenström, Cederholm TE. Nutritional status using mini nutritional assessment and subjective global assessment predict mortality in geriatric patients. J Am Geriatr Soc 2002;50(12):1996-2002.

30. Santos MRDR, Mendes SCSM, Morais DB, Coimbra MPSM, Araújo MAM. Caracterização nutricional de idosos com hipertensão arterial em Teresina, PI. Rev Bras Geriatr Gerontol 2007;10(1):73-86

31. Oliveira MRM, Fogaça KCP, Leandro-Merhi VA. Nutritional status and functional capacity of hospitalized elderly. Nutr J 2009;54:1-8.

32. Giacomin KC, Peixoto SV, Uchoa E, Lima-Costa MF. Estudo de base populacional dos fatores associados à incapacidade funcional entre idosos na região metropolitana de Belo Horizonte, Minas Gerais, Brasil. Cad Saúde Pública 2008;24(6):1260-70. 